\title{
REDEFINING THE "PROFESSIONAL" IN PROFESSIONAL ETHICS: AN INTERDISCIPLINARY APPROACH TO TEACHING PROFESSIONALISM
}

\author{
DAVID B. WILKINS*
}

\section{INTRODUCTION}

What does it mean to be a "professional"? The question lies at the heart of any attempt to teach professional ethics. Yet, despite its undeniable centrality, there is remarkably little consensus among the current generation of legal ethics teachers about what this term actually means beyond its obvious historical and descriptive connotations. Few would deny, of course, that lawyers have traditionally been considered "professionals" or that, in the minds of many, this designation carries with it certain normative implications about the relationship between lawyers and society that links the "legal profession" to the small number of other occupational groups (for example, doctors) that are also considered professionals. What has become quite controversial, however, is whether these normative claims are either true or, if true, socially desirable. Moreover, even among those who believe that the concept has some independent normative value worth preserving, the claim that "professionalism" can be taught remains deeply controversial. ${ }^{1}$

For the last three years, the Harvard Law School Program on the Legal Profession, with the generous support of the W.M. Keck Foundation, has been exploring the contemporary meaning of professionalism and developing new ways to impart the best aspects of this normative understanding to students. In this essay, I will report on one of these initiatives: an intensive course involving both law students and medical students entitled "Ethical Dilemmas in Clinical Practice: Physicians and Lawyers in Dialogue." This course, which was taught for the first time in January 1995, is part of a larger university-wide effort to

Copyright $(\mathcal{O} 1996$ by Law and Contemporary Problems

* Kirkland and Ellis Professor of Law and Director of the Program on the Legal Profession, Harvard Law School.

This essay was originally prepared for the W.M. Keck Foundation's symposium on Teaching Legal Ethics at Duke University School of Law, November 2 and 3, 1995. The author thanks the participants at that event and Dennis Thompson for comments on an earlier draft, as well as the W.M. Keck Foundation for its support of the conference and the initiatives at Harvard Law School described in this essay.

1. See Amy Gutmann, Can Virtue be Taught to Lawyers?, 45 STAN. L. REV. 1759 (1993) (cataloguing, but ultimately rejecting, the major criticisms to teaching lawyers professional virtue). 
develop an interdisciplinary dialogue about ethics and the professions. The central premise of this effort is that traditional teaching and scholarship about professions and professional ethics, both within professional schools and in other parts of the academy, has tended either to take the normative value of professionalism for granted or to divorce the study of this concept from the actual social and institutional contexts of professional work. In order to counteract these tendencies, Harvard brings together students and faculty from each of the major professional schools (law, medicine, business, and government), as well as scholars and graduate students interested in professions and professional ethics from other disciplines (for example, philosophy, sociology, and political science), to examine particular ethical problems confronting professionals and to discuss how these problems can enrich our general understanding of professionalism.

For the reasons stated below, we believe that our new course and the university-wide effort of which it is a part moves beyond the limitations that characterize traditional teaching and scholarship about professional ethics. Part II of this essay briefly sets out the theoretical underpinnings of traditional approaches to teaching about professionalism. Part III explains how Harvard's interdisciplinary approach seeks to reformulate this traditional understanding. Part IV describes the course and examines some of its principal accomplishments. Finally, Part V draws some tentative conclusions from our experience for future teaching and scholarship about professional ethics.

\section{II}

\section{THE Theoretical Background AND THE STATE OF THE FIELD}

The term "professional ethics" can be given at least three distinct, although admittedly interconnected, meanings. ${ }^{2}$ The most general understanding of the term refers to the ethics of "that entire family of vocations that we call 'the professions." "3 Those who subscribe to this meaning assume that it is possible to identify a stable set of criteria for classifying which occupations are entitled to be called professions and that all those who properly fall under this designation will share important normative commitments. ${ }^{4}$

The second meaning focuses on a particular profession, such as law, and attempts to identify those normative characteristics that are uniquely "profes-

2. See Paul Camenisch, Grounding Professional Ethics in a Pluralistic Society (1983) (discussing these three meanings). For other discussions about the multiple and often contradictory meanings given to professionalism, see David Trubek \& Robert Nelson, Arenas of Professionalism, in LAWYERS IDEALS/LAWYERS PRACTICES: TRANSFORMATIONS IN THE AMERICAN LEGAL PROFESSION (D. Trubek et al. eds., 1992) [hereinafter LAWYERS IDEALS].

3. CAMENISCH, supra note 2 , at 7 .

4. Talcott Parsons is probably the most influential exponent of this view. See, e.g., Talcott Parsons, Professions, in 12 INTERNATIONAL ENCYCloPEDIA OF THE SOCIAL SCIENCES 536 (David L. Sills ed., 1968). The most prolific contemporary advocate is Eliot Freidson. See Eliot Freidson, Professionalism as Model and Ideology, in LAWYERS IDEALS, supra note 2, at 215-29; see also CAMENISCH, supra note 2. 
sional." Unlike those who subscribe to the more general usage, persons interested in "legal ethics" need not claim that they can justify lawyers' professional status by some set of objective criteria or that the "professional" norms they identify will necessarily be shared by other professionals. Instead, these theorists tend to take professional status as a given and ask which ethical values lawyers ought to uphold in light of the legal profession's unique position in society. ${ }^{5}$

Finally, the last usage takes a descriptive and instrumental view of professional ethics. Rather than asking what norms professionals (either in general or in a particular profession) ought to share, those using the term in this third sense ask what ethics professionals actually display. This investigation into the meaning of professional ethics can be conducted at the level of both group ideology and individual behavior. At the collective level, scholars examine the official justifications offered by professionals for their ethical standards and ask whether these norms actually serve their stated purposes or instead are better understood as a convenient cover for actions that do little more than promote professional self-interest. ${ }^{6}$ With respect to individuals, the question asked is whether practitioners actually conform their conduct to the profession's articulated norms, values, and standards. ${ }^{7}$

Notwithstanding the fact that most scholars interested in professional ethics acknowledge the importance of all three understandings, one or the other of these approaches has tended to dominate each of the arenas in which professional ethics is generally taught. This segmentation has, in turn, nurtured and reinforced a growing cynicism among academics, practitioners, and the general public about whether the concept of professionalism has any independent normative content worth preserving.

Undergraduate and graduate level liberal arts courses that discuss professional ethics tend to embrace the first meaning. The question most frequently posed in these settings is whether there is something sufficiently distinctive about being a professional that justifies holding those occupying these social roles to normative standards that are different from the rules of common morality. ${ }^{8}$ For the most part, the academics who teach these courses tend to be skeptical about such claims. This skepticism comes from two quarters. First, many sociologists contend that it is impossible to identify a stable and objective set of criteria for separating existing professions from other occupations that, although desiring the social and economic benefits that flow from professional

5. See, e.g., ANThony T. Kronman, The Lost Lawyer: Failing Ideals of the Legal PROFESSION (1993); Monroe Freedman, Professional Responsibility of the Criminal Defense Lawyer: The Three Hardest Questions, 64 MICH. L. REV. 1469 (1966); Stephen Pepper, The Lawyer's Amoral Ethical Role: A Defense; A Problem, and Some Possibilities, 1986 AM. B. FOUND. RES. J. 613.

6. See, e.g., RAlPh NADER \& MARK GREen, VERDICT ON LAWYERS (1976); Richard Abel, Why Does the American Bar Association Promulgate Ethical Rules?, 59 TEX. L. REv. 639 (1981). (1985).

7. See, e.g., Deborah L. Rhode, Ethical Perspectives on Legal Practice, 37 STAN. L. REv. 589

8. See, e.g., Alan Goldman, The Moral foundations of Professional Ethics (1980). 
status, have had less success than doctors and lawyers in achieving their objectives. ${ }^{9}$ Second, philosophers are frequently critical of arguments that are premised on the existence of a "role differentiated morality," particularly where the argument asserts that people who occupy a given position in society are exempt from moral obligations that would govern the conduct of ordinary citizens. ${ }^{10}$

Collectively, these skepticisms cast doubt on the claim that professionalism per se has any independent moral content. Thus, to the extent that sociologists can convincingly demonstrate that lawyers and doctors achieved their current status as a result of concerted political struggle, the traditional structural/functionalist account that links professional status-and therefore professional ethics-to the unique functions that professionals perform for society is undermined. As a result, sociologists tend to view these normative claims as simply another tool that professionals use to pursue their objective of freeing themselves from state control and the constraints of the market. Consequently, although they begin by asking the question posed by the first understanding of professional ethics-what are the ethical claims that unite all professions?-the answers that these scholars give tend to devolve into the third approach that identifies self-interest as the common thread that unites all efforts to articulate a distinctive normative understanding of professional ethics. Similarly, once philosophers reject the idea that any group should be exempt from the demands of ordinary morality simply because they occupy a particular social role, there is no longer any reason to treat "professional ethics" as a separate and distinct area of moral inquiry. Once again, the overall effect is to shift the focus away from the norms and practices of particular professionals in favor of a more general examination of moral duties.

Not surprisingly, professional schools have tended to take a different tack. Required ethics courses in law schools are generally premised on the second model of professional ethics. Traditionally, these courses have started with the assumption that lawyers are "professionals" with their own unique ideals and practices. ${ }^{11}$ The task these courses set for themselves, therefore, is to identify which of these norms and practices are legitimate in light of the positions that lawyers occupy in society. In recent years, however, this standard orientation has increasingly come under attack. Taking as their inspiration many of the criticisms of the first model of professionalism outlined above, a growing number of legal ethics courses now include substantial criticism of both the selfinterested nature of many traditional professional ideals and of the standard claim that lawyers are not governed by the rules of ordinary morality.

9. See Magali Sarfatti Larson, The Rise of Professionalism: A Sociogocial analysis (1977).

10. See David Luban, Lawyers and Justice: AN ETHICAL Study (1988).

11. See Deborah L. Rhode, Ethics by the Pervasive Method, 42 J. Legal Educ. 31 (1992) (explaining and critiquing this standard orientation). 
Both of these approaches to formal ethics instruction in law schools undermine the claim that professionalism per se has independent moral content. The insularity of the standard orientation strongly implies that lawyers have nothing to learn from social scientists, or indeed from other professionals, about the normative content of the lawyer's role. Although the critical approach adopted by many contemporary ethics teachers substantially reduces this insularity, it also paradoxically reinforces the view that professionalism is either irrelevant or pernicious. In these courses, professionalism is largely identified with the standard version of legal ethics as articulated in the Code of Professional Responsibility, ${ }^{12}$ the Model Rules of Professional Conduct, ${ }^{13}$ and other official sources. The question, therefore, is whether lawyers should follow these professional rules or the dictates of their personal conscience when deciding difficult ethical problems. However one resolves this question in any particular case, this way of framing ethical issues deflects attention from investigating whether lawyers as professionals ought to reject both the traditional model of legal ethics and the assertion that they should simply follow the dictates of their personal morality. ${ }^{14}$ By omitting this third choice, legal ethics courses have left themselves vulnerable to the criticism that they either reify the narrow and often self-interested view of lawyer professionalism articulated in the current ethics rules or that they attempt to teach a personal moral code that bears little or no relationship to the competence or the mission of legal education. Collectively, these criticisms reinforce a skeptical attitude about the meaning of professionalism.

The implicit and sometimes explicit messages about lawyers' professionalism conveyed by the rest of the law school curriculum only serve to deepen this skeptical attitude. While formal ethics courses tend to portray the legal profession's traditional ideals as both legitimate and important (even when they are being critical), when "ethics" is mentioned in the rest of the curriculum the focus is on the third model's descriptive claim that ethical rules are either ignored in practice or simply a cover for lawyer self-interest. In cases, hypothetical examples, and off-hand remarks, lawyers are frequently portrayed as ruthless economic actors unconcerned with the "niceties" of the profession's traditional ethics. ${ }^{15}$ This skeptical attitude is reinforced by powerful intellectual movements in legal education that focus attention on the indeterminacy of rules (including ethical rules),${ }^{16}$ the need for functional as opposed to normative justifications for public policies, and the numerous ways in which law and

12. Model Code of Professional Responsibility (1981).

13. MODEL RULES OF PROFESSIONAL CONDUCT (1992).

14. See William Simon, Ethical Discretion in Lawyering, 101 HARv. L. REV. 1083, 1113-19 (1988) (criticizing the fact that ethical issues are frequently framed as a contest between "law" and "morality").

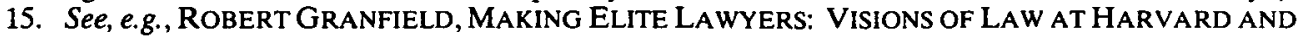
BEYOND (1992); Roger C. Cramton, The Ordinary Religion of the Law School Curriculum, 29 J. LEGAL EDUC. 247 (1978).

16. See David B. Wilkins, Legal Realism for Lawyers, 104 HARV. L. Rev. 468 (1991). 
lawyers entrench existing inequalities of wealth and power. ${ }^{17}$ At the same time, students who raise general ethical objections in traditional law school courses are often told that these concerns are irrelevant to the "legal" issues being discussed. When one puts all of these developments together, the clear message to law students is that lawyer professionalism, and indeed ethics in general, is either irrelevant to their lives or something to be deployed instrumentally to further their self-interest.

Indeed, the fact that philosophers, legal ethics teachers, and the rest of the law school faculty have largely failed to generate a meaningful account of the normative value of professionalism has had important consequences beyond the academy. As many commentators have noted, there is a growing separation between law schools and the legal profession itself. ${ }^{18}$ Each of the three approaches to professional ethics outlined above exacerbate this separation. By isolating the concept of "professionalism" from the actual practices of any group of professionals, the first definition leads many lawyers to believe that philosophers and other social scientists do not know (and probably do not care) enough about the realities of legal practice to render judgments that practitioners ought to heed. ${ }^{19}$

The second account embraced by most traditional legal ethics courses also tends to have the same effect. Although these courses purport to speak directly to practicing lawyers, they often present a stylized account of lawyering that bears little relationship to the realities of contemporary legal practice..$^{20}$ As a result, practicing lawyers often complain that law students are not being given the skills they need to cope with the massive changes that have transformed many areas of legal practice from the "gentlemanly" world of individual decisionmaking, apprenticeship, and noblesse oblige portrayed in most traditional ethics courses. ${ }^{21}$

Not surprisingly, the practicing bar resents the third account as well. To many practitioners, most legal academics know almost as little about the bar's actual ethical practices as the philosopher proponents of the first model. They therefore tend to dismiss these critics, as they have tended to dismiss most of

17. See Kronman, supra note 5 (arguing that "law and economics" and "critical legal studies" reinforce a skeptical attitude that undermines the legal profession's traditional values).

18. See, e.g., Harry T. Edwards, The Growing Disjunction Between Legal Education and the Legal Profession, 91 MICH. L. REV. 34 (1992).

19. See, e.g., M.B.E. Smith, Should Lawyers Listen to Philosophers About Legal Ethics, 9 L. \& PHIL. 67 (1990) (arguing that the answer is clearly no). Ironically, Smith himself is a philosopher who became a practicing lawyer later in life.

20. I explore this problem at some length elsewhere. See David B. Wilkins, Everyday Practice Is the Troubling Case: Confronting Context in Legal Ethics, in EVERYDAY PRACTICE AND TROUBLE CASES (A. Sarat ed., forthcoming 1996).

21. See, e.g., AMERICAN BAR Association, SECtion of Legal EdUCATION AND AdMissions to the Bar, Legal Education and Professional DeVelopment-AN Educational CONTINUUm, REPORT OF THE TASK ForCe ON LAW SCHOOLS AND the PROFESSION: NARROWing THE GAP (1992) [hereinafter MACCRATE REPORT] (criticizing law schools for failing to prepare students for the demands of legal practice). 
what is taught in law school, as being irrelevant to the contemporary realities of legal practice.

Ironically, when the bar formally attempted to define professionalism, it paid no more attention to the contemporary realities of legal practice than most traditional ethics courses. ${ }^{22}$ This failure further exacerbates the split between the bar and the academy by reinforcing the critical dimension of many contemporary legal ethics courses that portray the bar's understanding of professionalism as simply a cover for self-interest. At the same time, this critical attitude, as well as the even more openly cynical view of lawyers articulated in the mainstream legal curriculum, discourages practitioners from either acknowledging or confronting the difficult ethical problems caused by the growing bureaucratization and competitiveness of the market for legal services. This, in turn, simply fuels the claims by academics in both law schools and other parts of the university that the profession consistently fails to come to terms with academic criticism of its practices and its ideals. ${ }^{23}$

The net result of this dynamic, as with the segmentation of the three models of professionalism in general, has been to reinforce the cynicism by both academics and practitioners about the normative value of professionalism.

\section{III}

\section{HARVARD'S EFFORTS TO FOSTER INTERDISCIPLINARY ETHICS EDUCATION}

It is against this backdrop that Harvard University initiated the Program in Ethics and the Professions (the "University Program") in 1986. The University Program, which is jointly sponsored by the law school, the medical school, the business school, and the Kennedy School of Government, seeks to promote a cross-professional and interdisciplinary dialogue about professions and professional ethics. In order to accomplish this objective, the Program invites faculty teaching ethics in professional schools and scholars in academic departments such as philosophy, sociology, and political science to spend a year in residence at Harvard as Fellows examining issues of common concern. The Program consists of two parts: a seminar in which the Fellows examine ethical issues in various professional contexts, the social science literature on professions, and their own work in progress; and a formal lecture series in which scholars from a variety of different disciplines address important issues in professional ethics and moral theory as it relates to professions. The Fellows are also encouraged to take courses, to interact with students and faculty, and to participate in ethics-related events throughout the university.

22. See ABA Comm on Professionalism, "IN the SPIRIt of PUblic Service": A Blueprint FOR THE REKINDLING OF LAWYER PROFESSIONALISM (1986). For a critique of this report on the ground that it failed to discuss the contemporary realities of legal practice, see Trubek \& Nelson, supra note 2 , at 192-96.

23. See, e.g., Rhode, supra note 7. 
During the 1990-91 academic year, Dr. Linda Emanuel (Assistant Director of the Division of Medical Ethics at Harvard Medical School) and I were Fellows in the University Program. During that year, we had many conversations about the insights we were each gaining from being exposed to ethical issues in fields other than our own. We both felt that ethics instruction at our respective schools suffered from the shortcomings associated with the three traditional models of professional ethics described above and that our students had only a limited understanding of the ethical issues faced by other professions. We thought this lack of understanding was particularly unfortunate given the many areas in which lawyers and doctors work together. As a result, at the conclusion of that year, we decided that we would put the interdisciplinary concept into practice by jointly teaching a course on professionalism that would be open to both law and medical students. It was not until the Program on the Legal Profession received its grant from the Keck Foundation in 1992, however, that we were able to put our plans into action.

The course Dr. Emanuel and I taught in 1995 was the culmination of a tripartite effort to improve ethics teaching at Harvard Law School by encouraging dialogue across traditional substantive and institutional boundaries. $^{24}$ Through the first set of initiatives, we sought to break down the boundaries between ethics and the rest of the law school curriculum by encouraging faculty in regular substantive courses to integrate professional responsibility issues into their regular subject matter. ${ }^{25}$ Second, we attempted to forge a closer relationship between the profession and the academy by holding a series of colloquia in which academics and practitioners share ideas about concrete issues facing the profession. In keeping with the goals of the University Program, these events always include faculty from non-legal disciplines. ${ }^{26}$ Finally, we began to develop a series of advanced ethics courses

24. In addition to the iniatives discribed in the text, we also initiated a Keck Fellowship program in which distinguished practitioners, academics from other disciplines, and promising young scholars interested in teaching legal ethics are invited to spend anywhere from a day to a year at the law school teaching students, interacting with faculty members, and doing research on professional responsibility issues. To date, we have had 13 Keck Fellows. Deborah Hellman, who was a Keck Graduate Fellow during the 1993-94 academic year is now an Assistant Professor at the University of Maryland School of Law.

25. In the three years of the granting period, eight Harvard Law School faculty members added significant new ethics components to their non-ethics courses. For example, Professor Howell Jackson now regularly includes a two-part exercise on a lawyer's ethical obligations in representing federally insured institutions in his course on regulating financial institutions.

26. To date, we have held three such discussions. In April 1993, the Program on the Legal Profession held a roundtable discussion on ethical problems facing corporate general counsel. The one day event, which was attended by eight general counsels and more than a dozen academics from Harvard's law and business schools and the Kennedy School of Government, focused on how and when general counsel should advise the corporate board about ethical problems and methods for evaluating the professional performance of lawyers in these positions. In March 1995, the Program invited the authors of four recent books on lawyers to discuss the future of the legal profession with twenty practitioners and academics from around the country. Finally, in April 1995, the Program on the Legal Profession and the University Program sponsored a two-day conference entitled "The Right to Have Rights: A Discussion Between Political Philosophers and Lawyers." In this event, a group of 
designed to serve as building blocks for a new approach to understanding professional ethics that transcends the problems generated by the traditional trichotomy outlined in Part II.

If the concept of professionalism is to have a coherent meaning to today's practitioners, it can neither be divorced from nor subsumed by the realities of contemporary practice. Critics of the attempt to give some transcendental meaning to professional ethics are correct insofar as they point out that it is impossible either to generate a set of ahistorical criteria for determining which occupations qualify as "professions" or to provide a meaningful account of the attitudes, dispositions, or normative commitments that any given professional ought to hold on the basis of the abstract relationships between professionals and those they serve. Whatever may be said of ethics in general, professional ethics must be designed to serve specific societal needs. ${ }^{27}$ As such, it cannot be separated from the social, economic, and political contexts in which these needs arise and through which they must be met.

This does not mean, however, that we ought to confine our understanding of professional ethics to those norms and practices that have traditionally been the province of a single profession such as law. As David Luban and others persuasively argue, professional norms must always be justified in terms of some more general set of moral criteria. ${ }^{28}$ One important element of this inquiry is how the normative claims of the legal profession compare with those of other actors in society who are confronted with similar problems. Those who occupy social roles that have traditionally been thought of as professions provide one obvious source (though by no means the only source) for such comparisons. Moreover, given the complexity of modern social interactions and the breakdown of many traditional barriers to inter-professional cooperation and competition, members of different professions are increasingly likely to interact with each other in a variety of contexts. It is therefore critically important that these actors learn to understand one another and not to make demands that subvert one another's legitimate ethical practices.

This comparative approach, however, must not conflate professional ethics with personal ethics. Although common morality stands as the ultimate check on any assertion of professional ethics (and on the value of any cross-professional comparisons), it does not define the normative stance of professionals. Lawyers are more than ordinary citizens; they have been given a monopoly by the state to occupy a position of trust both with respect to the interests of their

prominent lawyers working on immigration and asylum issues and philosophers and political theorists discussed recent developments in law and academic theory.

27. See Deborah L. Rhode, Why the ABA Bothers? A Functional Perspective on Professional Codes, 59 TEX. L. REV. 689, 690 (1981) ("from a societal perspective, . . professional codes are desirable only insofar as they serve common goals to a greater extent than [available alternatives]"). I explore this issue as well as the general relationship between personal and professional ethics in David B. Wilkins, Practical Wisdom for Practicing Lawyers: Separating Ideals from Ideology in Legal Ethics, 108 HARV. L. REV. 458, 468-72 (1994).

28. See DAVID LUBAN, LAWYERS AND JUSTICE: AN ETHICAL STUDY (1988). 
clients and the public purposes of the legal framework. These unique responsibilities must be taken into account in defining a lawyer's professional obligations, even as we recognize that these obligations must account for the fact that lawyers are also individuals who are morally responsible for their own actions.

Finally, no attempt to provide a meaningful account of professional ethics can ignore the actual conduct of professionals. Without some attention to practice, professional ideals can easily degenerate into legitimation. ${ }^{29}$ Nor is it always appropriate to label the misdeeds of particular lawyers as individual deviance rather than as failings of the general ideals or practices. Certain officially sanctioned ideals or institutional arrangements make it more likely that individuals will transgress stated norms. More importantly, the substantive content that an individual practitioner gives to any ethical norm will inevitably be shaped by the institutional context in which the norm is developed and applied. ${ }^{30}$ Failure to pay attention to how these institutional structures shape lawyer conduct can both produce undesirable ethical norms as well as frustrate attempts to increase compliance with desirable ones. ${ }^{31}$

These observations have both theoretical and pedagogical significance for any attempt to create a new understanding of professional ethics. At the theoretical level, the new model must embrace the prevalent, but nevertheless often neglected truth that law is a practice that takes place in varying discrete institutional contexts. As a result, the goal of professional ethics instruction is to help students develop the skills, dispositions, and commitments that will allow them to navigate these complex arrangements in a manner that best promotes society's interest in the social goods produced by lawyers. While formal codes of conduct can sometimes be a useful guide, developing those traits of character that are particularly suited to the lawyer's role is at the core of what we ought to mean by professional ethics. ${ }^{32}$

Given these theoretical commitments, the pedagogy of a course designed to explore the contemporary meaning of professionalism must offer students both

29. I make this point in relationship to Anthony Kronman's attempt to define an ideal for lawyers independent of actual practice. See Wilkins, supra note 27, at 463-68; see also Trubek \& Nelson, supra note 2 , at $181-82$.

30. See Trubek \& Nelson, supra note 2 , at $185-88$ (discussing arenas of social construction). Trubek and Nelson's account builds on Jerome Carlin's pioneering study in which he determined that a lawyer's propensity to violate certain ethical norms varied according to the "ethical climate" in the firm, which was itself a function of the type of practice setting. See JEROME CARLIN, LAWYER's ETHICs (1966).

31. I have argued for this proposition extensively. See David B. Wilkins, Making Context Count: Regulating Lawyers after Kaye, Scholer, 66 S. CAL. L. REV. 1145 (1993); David B. Wilkins, Who Should Regulate Lawyers?, 105 HARV. L. REV. 799 (1992).

32. This understanding of "character" is distinct from the artificial "professional self" that traditional theorists posit as an antidote for unethical conduct in that it assumes that a lawyer's character, and hence his sense of what is both ethical and possible, is largely a function of his concrete experiences in the practice of law. See Trubek \& Nelson, supra note 2, at 182-85 (describing and critiquing the idea of a separate "professional self"). For a thoughtful discussion of the relationship between professional codes and character, see Heidi Li Feldman, Codes and Virtues: Can Good Lawyers Be Good Ethical Deliberators?, 69 S. CAL. L. REV. 885 (1996). 
a window on actual professional practice and a vantage point to discuss and evaluate these practices from a critical distance. As David Luban and Michael Millemann argue, the kind of ethical judgment lawyers most need to cultivate is best taught through "trial and error and by imitation." 33 Observing others, although not a perfect substitute for individual effort, can provide valuable insight and encourage the development of both empathy and critical judgment.

Cross-professional exchanges further these goals. When students observe professionals in other fields coping with issues that are present in the students' own discipline, they often see these problems in a new light. Not only must they consider, for example, the doctor's justification for her approach to informed consent or patient confidentiality, but they must also ask whether these justifications are persuasive in their own disciplines. Even this level of comparison, however, may fall short of fully addressing the problem of professional insularity. The very features that make the two groups similar may obscure the degree to which each subscribes to norms that unduly protect their respective professional prerogatives. Therefore, a course in professionalism must ultimately infuse the study of particular professional practices with normative perspectives from disciplines such as philosophy, sociology, psychology, and political science that stand outside the traditional discourse of professionalism.

To the extent practicable, Dr. Emanuel and I tried to design a course that was true to these theoretical and pedagogical commitments.

\section{IV}

\section{THE COURSE}

Three principles guided our decisions about course content and methodology. First, we wanted to create a course that would speak directly to the meaning of professionalism. We therefore avoided many of the usual topics covered in courses that combine elements of law and medicine such as medical malpractice, hospital law, or the admissibility of medical testimony. ${ }^{34}$ Instead, we focused on issues that presented concerns central to the self-conception of each profession.

Second, we wanted the course to be interdisciplinary in the fullest sense of the term. Because the course was open to students from both the law and medical schools, it had to be taught during the law school's intensive January term, since this was the only time that the schedules of the two schools overlapped. ${ }^{35}$ We also taught half of the classes in each school and included

33. David Luban \& Michael Millemann, Can Judgment be Taught? Ethics Teaching in Dark Times, 9 GEO. J. LEGAL ETHICS 31 (1995).

34. As I explain below, we did use a medical malpractice case for our moot court exercise.

35. During the month of January, Harvard law students take one course that meets every weekday for two or three hours (the equivalent of a two- or three-credit course meeting once a week for 15 weeks). At all other times, law school courses run for either a semester or a year. After their first two years, medical students take all of their courses and clinical placements in one-month intervals. 
an equal number of academics and practitioners from both fields as guest lecturers. The course also featured lecturers trained in philosophy, political theory, sociology, and economics.

Third, we were committed to exploring the connection between norms and practices. We therefore limited enrollment to students who had some clinical experience (third- and fourth-year medical students and second- and third-year law students with either summer or extra-curricular clinical experience). In addition, every student was required to make a series of site visits outside of their own field: The law students spent time in a hospital emergency room, a neonatal or cardiopulmonary intensive care unit, and an internist's office; the medical students went to criminal court, a legal aid office, and landlord-tenant court. $^{36}$ Finally, each student participated in three role-playing exercises: drafting a model statute on the definition of death; a moot court trial of a medical malpractice action; and a simulated meeting of a hospital ethics committee.

We divided the course into four sections, each running for approximately one week. The first week consisted of a four-part examination of the core elements of professionalism. In the first session, Dr. Emanuel and I each presented brief overviews of the two professions, including organizational structures, demographics, and codes of ethics. The second session, conducted by Dr. Stockle, an internist at Massachusetts General Hospital, and Professor Robert Gordon of Yale Law School, examined the two relationships at the heart of professional practice: the doctor/patient-lawyer/client relationship and collegial relations among doctors and lawyers. The next session featured Dr. Arnold Relman, former editor-in-chief of the New England Journal of Medicine, and Professor Dennis Thompson, Director of the University Program in Ethics and the Professions, discussing institutional ethics with a particular emphasis on conflicts of interest. In the fourth session, Dr. Cyrus Hopkins of Harvard Medical School and I examined methods of reasoning, including ethical reasoning, in law and medicine. The majority of site visits were also scheduled for this first week. ${ }^{37}$

In the second week, we turned our attention to specific issues surrounding the allocation of decisionmaking authority between the two groups of professionals and those they purport to serve. The centerpiece of this week was a drafting exercise of a model statute on the definition of death. In the first session, Dr. Alan Weisbard of the University of Wisconsin Law and Medical Schools gave students an overview of the issues surrounding the definition of death, including medical and legal problems with the concept of "brain death" and other traditional formulations. He also discussed the effect of any potential standard on issues such as organ donation, religious freedom, and personal

36. A planned visit to a large corporate law firm was canceled due to scheduling problems.

37. Our intention was to have all the site visits completed by the end of the first week. This proved to be logistically impossible. 
autonomy. After this introduction, the students were divided into two teams for the purpose of drafting a model statute. The goal of this exercise was to encourage students to reflect on the ethical issues confronting doctors in this area and to examine how lawyers (in their capacities as drafters and interpreters of legislation) ought to take the medical profession's concerns into account. While the students were drafting, Dr. Emanuel discussed patient self-determination in the context of advance directives concerning life-prolonging care. Dr. Emanuel was joined in this session by Professor Susan Koniak of Boston University Law School who examined client self-determination in the legal context. The next session, conducted by Professors Robert Truog, a neonatologist at Children's Hospital in Boston, and Elizabeth Bartholet of Harvard Law School addressed the unique problems that arise when the patient or client is a minor. Finally, Dr. Paul Appelbaum and Harvard Law Professor Lucy White discussed the practical and ethical dilemmas involved in obtaining informed consent in law and medicine. At the conclusion of the week, the student teams presented and defended their model statutes.

The third week was devoted to examining risk and research in professional practice. In the first session on professional risks, Dr. Lynn Peterson, Director of the Harvard Medical School Division of Medical Ethics and a practicing surgeon, discussed the ethics of treating patients with HIV and other contagious diseases. Harvey Silverglade, a long-time criminal defense and civil rights lawyer in Boston, discussed the risks associated with representing an unpopular defendant against the government. The second session was devoted to the ethical problems associated with research both by and about professionals. Doctors Kenneth Ryan and Allan Brandt of Harvard Medical School and History of Science Department respectively, examined the ethical implications of "research integrity" in human subject experimentation. Professor Robert Nelson of the American Bar Foundation and Northwestern University Sociology Department discussed the difficulty of obtaining reliable empirical data on lawyers and the implications of this lack of knowledge for debates about professional practice. We then turned our attention to the academy, where Dean Federman of the Harvard Medical School and Michael Meltsner, the former dean of Northeastern Law School discussed the differing approaches to professional education in the two fields. Dr. Susan Pauker of Harvard Medical School and Professor Dorothy Roberts of Rutgers University School of Law completed the week by examining how technologies like genetic screening will present both doctors and lawyers with new and difficult ethical problems.

During this week, the students also prepared and participated in a moot court exercise. The case, which was supplied by the National Institute for Trial Advocacy, involved a lawsuit by a patient against her former doctor for damages allegedly stemming from unsuccessful breast reconstruction surgery. ${ }^{38}$ In

38. MiChelle G. HeRmAN, KING v Rogers: CASE File (1st ed. 1986)(unreported case available from the National Institute for Trial Advocacy). 
keeping with our general orientation, the purpose of the exercise was not to teach the students about the law of medical malpractice. Instead, our goal was to open a lens on each profession's views about resolving disputes over the delivery of professional services through adversarial adjudication. Thus, we wanted the law students to experience the anger and frustration that doctors feel when their professional practices are evaluated by lay juries. Similarly; we hoped that medical students would reflect on why lawyers believe the adversarial nature of trials justifies legal tactics (for example, discrediting witnesses) that appear to obscure the truth. To that end, medical students were assigned to play all of the major legal roles, while law students filled the medical positions. At the conclusion of the trial, students were debriefed about the ethical issues they perceived both in their roles and in the process as a whole.

In the final week, we covered two general issues that have become increasingly important to professionals in both medicine and law: causation and government regulation. With respect to the first issue, Dr. Leon Eisenberg of Harvard Medical School and Professor David Rosenberg of Harvard Law School examined how expanding notions of causation create difficult problems in both medicine and law. With respect to the second issue, Dr. Ezekial Emanuel of Harvard Medical School and Professor David Charny of Harvard Law School examined how government in its role as both provider of professional services (either through insurance schemes such as Medicaid and Medicare or through government-funded health clinics and legal aid offices) and as regulator of professional conduct is redefining the norms and practices of both doctors and lawyers.

The bulk of this last week, however, was devoted to preparing for and conducting a simulated meeting of a hospital ethics committee. The scenario for the exercise involved a doctor who reported false information to a patient's insurance company in order to get the insurer to pay for genetic screening that the doctor believes is in the patient's best interest but to which the patient is admittedly not entitled under the existing guidelines agreed upon between the hospital and the insurance company. The students were assigned roles both on the committee (including a hospital administrator, the general counsel, the chief of surgery, and an outside ethics expert) and as witnesses on behalf of the doctor, the hospital, and the insurance company. Wherever possible, students were assigned to roles outside of their professional sphere. The rest, however, was up to the students, who designed both the committee's procedural and decisional rules as well as the substance of the views they would espouse in their various roles. Once again, our goal was to teach students about the realities of professional decisionmaking as opposed to either the medical or legal implications of genetic screening. As with the moot court experience, students were given an opportunity to discuss their reactions to the exercise, as well as to the class as a whole, at the conclusion of the hearing.

By any measure, the course was extremely successful. Students from both schools gave the course the highest rating on their evaluations, with many 
stating it was the best course they had taken in professional school. These ratings are especially significant in light of the initial skepticism, particularly on the part of medical students, about the value of a course of this kind. ${ }^{39}$ Moreover, although students received only two credits, the work load was as onerous and intense as any of the most demanding classes in either school.

More importantly, the combination of observation, role-playing, and reflection appears to have given students important, concrete insight into what it means to be a professional in both law and medicine. The site visits and the role-playing exercises alerted students to the difficulties faced by professionals in both disciplines. From the simple fact of having to be in the hospital by 6:00 a.m., to the realization that an internist may have has less than ten minutes to listen to a patient's complaints and reach a preliminary diagnosis, the law students came away with a new understanding of the difficulty of getting informed consent or encouraging patient self-determination in the pressure-filled world of contemporary medicine. For their part, the medical students stated that their courtroom visits and the experience of "actually" representing a client in the various role-playing exercises allowed them to see clearly the moral tension inherent in the lawyer's role and how easy it is to be swept up in the grip of adversarial zeal. Indeed, in the statutory drafting exercise, all of the students became so engaged in their roles that in the interest of getting the students to continue to work together, Dr. Emanuel and I gently reminded them that the process was not real.

Similarly, there were many instances in which the comparative focus caused both students and faculty (including Dr. Emmanuel and me) to reevaluate our own professional ideals and practices. For example, with respect to conflicts of interest, Dr. Relman conceded that the medical profession could learn a great deal from the way lawyers identify and address such conflicts. On the other hand, lawyers are only beginning to think about the ethical implications of the kind of institutional structures, government regulation, and third-party payment schemes that have confronted physicians for more than a decade.

Most fundamentally, the course produced some tantalizing insights about the general meaning of professionalism. Not surprisingly, these insights relate to character and judgment. Whether the discussion was about how lawyers and doctors "diagnose" problems and design potential solutions, or about the reasons why some professionals are prepared to risk their physical safety, defy authority, or genuinely listen to their clients' or patients' needs while others are not, lecturers from both professions argued that rules, procedures, and sanctions could never fully define, let alone produce, proper ethical conduct. Judgment

39. The fact that it was easier to convince law students than medical students to take the course is undoubtedly due in large measure to the students' differing opportunity costs. In order to take the class, third-year medical students must either delay or give up one of their medical rotations while fourth-year students generally do not have to take classes at all by January. Law students, on the other hand, need only decide whether to take this course or some other intensive class during the month of January in both their second and third years. 
and character, according to the nearly unanimous view of all participants, hold the key to understanding the proper meaning of "professional" in professional ethics.

The course also offered some tentative clues about how professional character and judgment are shaped and constrained by institutional forces both within the academy and in the world of practice. From the feel of the classrooms to the lecturing styles of faculty members, professional education shapes lawyers and doctors in subtly different ways. Notwithstanding the apparent formality of the law school classroom, lawyers are taught to argue and challenge authority from the moment they arrive. Moreover, most law school teachers know relatively little, either from their own experience or from sustained study, about legal ethics. Nor does legal education offer any formal avenue for law students to form mentoring relationships with lawyers who have this kind of experience or knowledge.

Medical students, on the other hand, spend the first two years of their education passively absorbing large quantities of data and immediately enter into complex hierarchical relationships in which they start at the bottom with the expectation that they will eventually work their way to the top. At the same time, these relationships offer medical students an opportunity for mentoring and a real immersion in the medical profession's ideals unmediated (or at least only partly mediated) by the profit motivations that attend mentoring relationships in law to the extent that they exist at all.

Each of these respective educational tracks creates unique problems for developing professional character and judgment. Given the relative absence of professional role models and the constant emphasis on being able to argue the opposite side of every proposition, it is not surprising that law students often develop a kind of cynicism about professional norms captured by the third model of professional ethics. The medical students, on the other hand, were far less cynical about their profession's ethical traditions. In their case, the problem was getting them to examine these traditions critically. As the course progressed, however, these two positions began to converge as each group of students was placed in the position of both justifying and critiquing its own and the other group's professional practices.

Once these new professionals enter the working world, the institutional structures in which they practice are also likely to produce their own effects. Dr. Truog's and Professor Bartholet's discussion of the unique ethical problems that arise when the patient or client is a minor nicely illustrates this point. Dr. Truog described a case involving a clinical trial of a potentially life-saving therapy for critically ill infants. ${ }^{40}$ According to Dr. Truog, the physicians involved in the trial probably would have refused to participate if the terms of the experiment had required them to treat one of their own patients with a

40. For a full description of this problem, see Robert D. Truog, Randomized Controlled Trials: Lessons from ECMO, 40 CLINICAL RES. 519 (1992). 
therapy they believed less effective than an available alternative. These same doctors, however, readily consented to a procedure for obtaining randomized consent that consigned some of these same critically ill babies to the less effective therapy without informing their guardians of the potentially more effective alternative. As Truog argues, the institutional structure of the trial, including the fact that the babies who were not offered the potentially more effective therapy were sent to a different floor of the hospital where they were treated by a different group of doctors (from different specialties), helped obscure the ethical problems attending the consent procedures.

Similarly, Professor Bartholet in her discussion about how the legal system fails to protect the rights of children in child custody and adoption cases argued that the institutional framework in which these cases are decided often blinds lawyers and judges to the ethical issues at stake. Thus, given their role as "zealous advocates," lawyers who represent custodial parents are frequently either unable or unwilling to recognize when their client may be unfit to care for a child. At the same time, the judge who has the responsibility for deciding what is in the "best interest of the child" must make this determination based on information supplied by a social welfare system that often has institutional interests that cloud the judgment of participants about what is best for the child.

These and other insights that emerged throughout the course began to open a window on the complex process by which professional norms are developed and learned. The task for the future is to develop curricular innovations that will allow us to continue investigating this crucial process.

\section{$\mathrm{V}$}

\section{CONCLUSION: THE FUtURE OF PROFESSIONAL ETHICS}

The Program on the Legal Profession, in conjunction with the University Program, is committed to refining and expanding our interdisciplinary approach to teaching professional ethics. I am currently in discussions with faculty members from the business school and the Kennedy School of Government about designing similar courses that explore the relationship between lawyers and other professionals in business and government. In addition, Harvard University Press has approached Dr. Emanuel and me about putting our course together as a book that could be used by faculty at other schools.

Despite these opportunities and our enthusiasm for the approach, any attempt to duplicate or expand on our previous efforts must overcome a daunting array of obstacles. I close by briefly addressing three of the most important.

The first and most obvious is money. Assembling this talented array of academics and practitioners and providing students with access to all of the opportunities for site visits and simulated instruction was expensive. If it were not for the generous support of the Keck Foundation, the course would not have been offered. To be sure, some of the benefits of this course can be achieved at a lower cost. For example, we could confine ourselves to Harvard 
faculty members or even rely on articles and other secondary sources. Each of these compromises, however, would subtly, but nevertheless perceptibly alter the experience.

Even if courses of this kind are adequately funded, the logistical problems are almost enough to discourage anyone from going forward. Chief among these is the calender. As I indicated above, January is the only month where the law and medical schools' calenders overlap. For a variety of reasons, this time is less than ideal for all concerned. Although we are investigating alternatives, the difficulty of finding a time for an interdisciplinary course that is even minimally convenient to all interested parties is daunting in the extreme.

Finally, and most importantly, there is the problem of knowledge. Specifically, we know far too little about the institutions and practices of all professionals, including lawyers. Courses such as this one depend for their success on painting an accurate portrait of the real ethical problems that confront practitioners in their day-to-day lives. We simply do not know enough about the subtle, but crucial differences among institutions and practice settings to understand how these forces influence the development of professional judgment and other valuable traits of character. What is needed, as others have eloquently argued in this issue of Law and Contemporary Problems, is an interdisciplinary research program that would complement the new approach to teaching about professionalism exemplified by this course. ${ }^{41}$

In the end, however, something like this course is a necessary step in building a normative understanding of professionalism for lawyers in the twentyfirst century. The goal is not to replace traditional ethics courses, although some of the methodologies and examples we developed could and should be incorporated into these courses. Nor are these courses a substitute for the kind of direct engagement with ethical problems that students gain in their clinical courses. Nevertheless, if we expect our students to value "professional ethics," we must begin to provide them with an account of lawyer professionalism that neither reifies existing practices nor devolves into their own personal moral commitments. Teaching professional ethics through an interdisciplary approach provides our best opportunity to forge this new understanding.

41. See, e.g., Paul Brest, The Responsibility of Law Schools: Educating Lawyers as Counselors and Problem Solvers, 58 LAW \& CONTEMP. PROBS. 5 (Summer/Autumn 1995); Susan P. Koniak \& Geoffrey C. Hazard, Jr., Paying Attention to the Signs, 58 LAW \& CONTEMP. PROBS. 117 (Summer/Autumn 1995). 